\title{
Genetics of exceptional longevity: possible role of GM allotypes
}

\author{
Calogero Caruso ${ }^{1 *}$, Janardan P. Pandey ${ }^{2}$ and Annibale A. Puca ${ }^{3,4}$
}

Keywords: Case control studies, GM allotypes, GWAS, Immune response, Longevity

\section{Background}

Many variables contribute to the way we age and the consequent possible achievement of extreme ages. Among these, we can include cultural, anthropological and socio-economic status as well as sex and gender (women live longer than men). Also, ethnic differences (explained by discrepancies in healthcare, environmental and economic status, genetics as well as life occupation) exist in relation to ageing/longevity. In any case, the concrete possibility to manifest a longevity phenotype is strictly related to the stochastic interactions due to accidental events, with environmental and genetic factors having a role in ageing and longevity processes. The genetic component is progressively a major determinant as we evaluate extreme ages to be reached. Indeed, the possibility to inherit longevity increases with age: for long living individuals (LLIs), which are people that belong to the top 5th percentile of life-spans (i.e. 95 years in males and 98 years in female), it reaches up to $33 \%$ for women and $48 \%$ for men [1-3] (https://www.ssa.gov/OACT/STATS/, under "life table").

Genetics of exceptional longevity has been developed with different approaches depending on the available technologies and on the costs for a single analysis. Although the reduced costs have allowed more comprehensive studies, more is not always better. As an example, given the number of samples available for a given genetic analysis, the power of the study is reduced progressively as we add more hypothesises to test, to the point that the study becomes underpowered in genome-wide association studies (GWAS) [4].

In other words, there is no simple equation, such as more hypotheses $=$ more results. Indeed, APOE $\varepsilon 4$ allele was associated with exceptional longevity in 1994 through

\footnotetext{
* Correspondence: calogero.caruso@unipa.it

${ }^{1}$ Department of Pathobiology and Medical Biotechnologies, Section of General Pathology, University of Palermo, Corso Tukory 211, 90134 Palermo, Italy Full list of author information is available at the end of the article
}

a candidate gene approach using a small sample size [5]. Since then, many replication attempts were successful, despite the fact that there is a strong gradient in terms of $\varepsilon 4$ allele frequency among Northern and Southern European studies (lower in the South) [6]. APOE was so strongly associated that it came up in most GWAS for exceptional longevity, surviving the Bonferroni's correction of the threshold of significance adopted for GWAS $\left(p<5 \times 10^{-8}\right)$. This is also true for the FOXO3A locus, while for others replication attempts were not consistent, possibly due to the multiple testing that reduced the threshold of significance $[7,8]$. Thus, in the era of candidate gene studies in exceptional longevity, the limitation was not underpowered studies, but the lack of correction for genetic admixture. Indeed, stratification, which is the bias that brings to an enrichment of a specific ethnicity in one of the two arms (cases and controls) of the study, is the main cause of false positive results [4].

In an attempt to reconcile the results of different studies, statistics that included different studies (meta-analysis) was developed. Still, the non-homogeneous criteria adopted to select the two arms of a case-control study could result in conflicting results. Among the criteria that vary among the studies, it is important to mention the ages of LLIs and the young controls and gender distribution, parameters that could influence associations of genetic variants that intervene at extreme ages and with a gender effect [9].

Recently, many studies have been accomplished using chip arrays that interrogated hundreds of thousands of single nucleotide polymorphisms (SNPs,) followed by the imputation of the missing SNPs allowing a comprehensive analysis of the entire genome, with some exceptions where polymorphisms were not well represented at the chip level. Furthermore, the Bonferroni's correction is a strong killer for genetic risk factors with small effects unless the number of individuals tested is in the 
tens of thousands. The LLIs are healthy individuals that are not hospitalized and are recruited by home visiting, making it difficult to reach large numbers [4].

\section{Discussion}

Candidate gene studies involving the genomic regions that are not well represented in the SNP arrays are therefore welcome for the discovery of new potential associations with exceptional longevity. It is useful to adopt populations that have already been used for GWAS so as to exclude stratification effects. This is indeed the case for the study presented by Puca et al., [10] which analysed the role of genetic markers of $\gamma$ chains (GM allotypes), i.e. the hereditary antigenic determinants expressed on immunoglobulin G polypeptide chains, in the attainment of longevity. In this study, the DNA samples from 95 LLIs (mean age 96.7) and 96 young controls (mean age 31.9) from South Italy were typed for GM3/17 and GM23+/- alleles, showing that GM3 allotype is significantly overrepresented in both male and female LLIs. The rs1071803 SNP that codes for the GM 3/ 17 (arginine/lysine) allotypes is not represented in the commonly employed genotyping platforms. It can be imputed, but the quality of imputation is poor.

Literature data show that human longevity may be correlated with optimal functioning of the immune system, so suggesting that genetic determinants of longevity also resides in those polymorphisms for the immune system genes that regulate immune responses, such as human leukocyte antigen (HLA) [11, 12]. Accordingly, several studies have examined the role of HLA antigens in longevity [11, 13]. It has been known since at least 1971 [14] that GM allotypes contribute to the interindividual differences in the magnitude of immune responsiveness, so it is not surprising that GM allotypes are seemingly associated with longevity, it is instead surprising that until now no study was performed on GM allotypes and longevity.

As first suggested by J.B.S. Haldane [15], major infectious diseases have been the principal selective forces in shaping our evolutionary history. GM allotypes have been shown to be associated with immune responsiveness to several major infectious pathogens and with survival from epidemics [16]. One mechanism for how GM determinants could contribute to the outcome of infection with various agents may be through allotype-mediated antibody responses against pathogens, resulting in differential immunity to infectious diseases. Thus, GM allotypes could participate as recognition structures for the pathogenic epitopes on B cell membranes. Additionally, and contrary to the prevalent belief in immunology, these constant-region determinants could directly influence antibody specificity by causing conformational changes in the antigen-binding site in the immunoglobulin variable region. They could also influence the expression of idiotypes involved in immunity to the pathogens. Contribution of both variable and constant regions in the formation of idiotypic determinants was documented many years ago [17].

\section{Conclusion}

Human population is very heterogeneous because of the different genetic background and different environmental stimuli, so it has not yet been possible to identify a clear signature of longevity with the exception of APOE and FOXOA. The study of Puca et al., [10] was performed in a very homogeneous population from South Italy, so the observed association of GM with longevity should not depend on population stratification. However, further studies are necessary to confirm this association. GM17/17 (the alternative allele of GM3) has been shown to be associated with the risk of developing HCMV symptomatic infection [18]. Considering the role of HCMV in immunosenescence [19, 20], future studies might evaluate antibodies titers directed versus HCMV in LLIs and young controls, according to GM3 allotype.

\section{Abbreviations}

APOE: apolipoprotein E; GM: genetic markers of $y$ chains; GWAS: genome-wide association studies; HCMV: human cytomegalovirus; HLA: human leukocyte antigen; LLI: Long-living individual; SNP: single nucleotide polymorphism

\section{Acknowledgements \\ None. \\ Funding \\ Original work was supported by grant he study was supported by Cariplo Foundation (n.2016-0874) and by Italian Ministry of Health (Ricerca Corrente, RF-2011-02348194) to A.P. and by grant of Italian Ministry of University (PRIN: progetti di ricerca di rilevante interesse nazionale - Bando 2015 Prot 20157ATSLF "Discovery of molecular and genetic/epigenetic signatures underlying resistance to age-related diseases and comorbidities") to AP, CC.}

\section{Availability of data and materials}

Not Applicable.

Authors' contributions

All the Authors contributed to write the paper and to edit it. They approved its final version.

Ethics approval and consent to participate

Not applicable.

\section{Consent for publication}

Not applicable.

\section{Competing interests}

Prof. Caruso is the Editor in Chief of Immunity \& Ageing. The other authors declare that they have no competing interests.

\section{Publisher's Note}

Springer Nature remains neutral with regard to jurisdictional claims in published maps and institutional affiliations.

\section{Author details}

'Department of Pathobiology and Medical Biotechnologies, Section of General Pathology, University of Palermo, Corso Tukory 211, 90134 Palermo, Italy.

${ }^{2}$ Department of Microbiology and Immunology, Medical University of South 
Carolina, Charleston, SC 29425, USA. ${ }^{3}$ Department of Medicine and Surgery, University of Salerno, Baronissi, Italy. ${ }^{4}$ IRCCS MultiMedica, Milan, Italy.

Received: 14 August 2018 Accepted: 19 October 2018

Published online: 06 November 2018

\section{References}

1. Avery P, Barzilai N, Benetos A, Bilianou H, Capri M, Caruso C, Franceschi C, Katsiki N, Mikhailidis DP, Panotopoulos G, Sikora E, Tzanetakou IP, Kolovou G. Ageing, longevity, exceptional longevity and related genetic and non genetics markers: panel statement. Curr Vasc Pharmacol. 2014;12:659-61.

2. Accardi G, Caruso C. Updates in Pathobiology: Causality and Chance in Ageing, Age-Related Diseases and Longevity. In: Accardi G, Caruso C, editors. Updates in Pathobiology: causality and chance in ageing, agerelated diseases and longevity. Palermo: University Press; 2017. p. 13-24.

3. Puca AA, Spinelli C, Accardi G, Villa F, Caruso C. Centenarians as a model to discover genetic and epigenetic signatures of healthy ageing. Mech Ageing Dev. 2018;174:95-102.

4. Ferrario A, Villa F, Malovini A, Araniti F, Puca AA. The application of genetics approaches to the study of exceptional longevity in humans: potential and limitations. Immun Ageing. 2012;9:7.

5. Schächter F, Faure-Delanef $L$, Guénot F, Rouger $H$, Froguel $P$, Lesueur-Ginot $\mathrm{L}$, Cohen D. Genetic associations with human longevity at the APOE and ACE loci. Nat Genet. 1994;6:29-32.

6. Lucotte $G$, Loirat F, Hazout S. Pattern of gradient of apolipoprotein E allele *4 frequencies in western Europe. Hum Biol. 1997;69:253-62.

7. Sebastiani P, Solovieff N, Dewan AT, Walsh KM, Puca A, Hartley SW, Melista E, Andersen S, Dworkis DA, Wilk JB, Myers RH, Steinberg MH, Montano M, Baldwin CT, Hoh J, Perls TT. Genetic signatures of exceptional longevity in humans. PLoS One. 2012;7:e29848.

8. Broer L, Buchman AS, Deelen J, Evans DS, Faul JD, Lunetta KL, Sebastiani P, Smith JA, Smith AV, Tanaka T, Yu L, Arnold AM, Aspelund T, Benjamin EJ, De Jager PL, Eirkisdottir G, Evans DA, Garcia ME, Hofman A, Kaplan RC, Kardia SL, Kiel DP, Oostra BA, Orwoll ES, Parimi N, Psaty BM, Rivadeneira F, Rotter It, Seshadri S, Singleton A, Tiemeier H, Uitterlinden AG, Zhao W, Bandinelli S, Bennett DA, Ferrucci L, Gudnason V, Harris TB, Karasik D, Launer LJ, Perls TT, Slagboom PE, Tranah GJ, Weir DR, Newman AB, van Duijn CM. Murabito JM. GWAS of longevity in CHARGE consortium confirms APOE and FOXO3 candidacy. J Gerontol A Biol Sci Med Sci. 2015;70:110-8.

9. Sebastiani P, Bae H, Gurinovich A, Soerensen M, Puca A, Perls TT. Limitations and risks of meta-analyses of longevity studies. Mech Ageing Dev. 2017; 165(PtB):139-46.

10. Puca AA, Ferrario A, Maciag A, Accardi G, Aiello A, Gambino CM, Candore G, Caruso C, Namboodiri AM, Pandey JP. Association of immunoglobulin GM allotypes with longevity in long-living individuals from southern Italy. Immun Ageing. 2018. https://doi.org/10.1186/s12979-018-0134-7

11. Caruso C, Candore G, Colonna Romano G, Lio D, Bonafè M, Valensin S, Franceschi CHLA. Aging, and longevity: a critical reappraisal. Hum Immunol. 2000:61:942-9

12. Gambino CM, Aiello A, Accardi G, Caruso C, Candore G. Autoimmune diseases and 8.1 ancestral haplotype: an update. HLA. 2018:92:137-43.

13. Caruso C, Candore G, Romano GC, Lio D, Bonafè M, Valensin S, Franceschi C. Immunogenetics of longevity. Is major histocompatibility complex polymorphism relevant to the control of human longevity? A review of literature data. Mech Ageing Dev. 2001;122:445-62.

14. Wells JV, Fudenberg HH, MacKay IR. Relation of the human antibody response to flagellin to GM genotype. J Immunol. 1971;107:1505-11.

15. Lederberg J. J.B.S. Haldane (1949) on infectious disease and evolution. Genetics. 1999;153:1-3.

16. Oxelius VA, Pandey JP. Human immunoglobulin constant heavy $G$ chain (IGHG) (fcy) (GM) genes, defining innate variants of $\lg G$ molecules and $B$ cells, have impact on disease and therapy. Clin Immunol. 2013;149:475-86.

17. Morahan G, Berek C, Miller JFAP. An idiotypic determinant formed by both immunoglobulin constant and variable regions. Nature. 1983;301:720-2.

18. Di Bona D, Accardi G, Aiello A, Bilancia M, Candore G, Colomba C, Caruso C, Duro G, Gambino CM, Macchia L, Pandey JP. Association between y marker, human leucocyte antigens and killer immunoglobulin-like receptors and the natural course of human cytomegalovirus infection: a pilot study performed in a Sicilian population. Immunology. 2018;153:523-31.

19. Pawelec G, Akbar A, Caruso C, Effros R, Grubeck-Loebenstein B, Wikby A. Is immunosenescence infectious? Trends Immunol. 2004;25:406-10.

20. Pawelec G, Akbar A, Caruso C, Grubeck-Loebenstein B, Solana R, Wikby A. Human immunosenescence; is it infectious? Immunol Rev 2005:205·257-68.

\section{Ready to submit your research? Choose BMC and benefit from:}

- fast, convenient online submission

- thorough peer review by experienced researchers in your field

- rapid publication on acceptance

- support for research data, including large and complex data types

- gold Open Access which fosters wider collaboration and increased citations

- maximum visibility for your research: over $100 \mathrm{M}$ website views per year

At BMC, research is always in progress.

Learn more biomedcentral.com/submissions 